\title{
Dickson Ogbonnaya
}

DOI: https://doi.org/10.15804/rop2021306

\section{THE SOCIOCULTURAL PERSPECTIVE OF FARMERS-HERDERS CONFLICT AND NATIONAL INTEGRATION}

Key words: Sociocultural, Farmer-Herder, Migration, Identity, Conflict, National integration

\begin{abstract}
Globally, sociocultural component of social relations weaves into shades of interactions including one existing between Farmers-Herders in their agricultural engagements to generate value that strengthens national integration. Migration pattern and choice expose migrant's cross-cultural contact without insulating both sides from conflict which however, is a social fact and reality of all social relations. Drawing from the foregoing, the study argues that there is conflict of culturally derived identity interest among returning and settler's migrants in first contact like in the case of Farmers-Herders, however, is largely a major conflicts driver that endangers sense of patriotism needed for national integration. It further argues that interest quest enables national consciousness and cultural chauvinism and that determines access and denial. However, while a lot of researches have gone into Farmers-Herders contact and conflicts, little of the sociocultural context of their interactions is known in northeast geopolitical zone of Nigeria. Hence, the focus of this study is to examine the sociocultural perspective of farmers-herders conflict as a challenge to national integration. Using Frustration-Aggression theory as framework, the exploratory research adopted qualitative approach to gather data via the conduct of 18 in-depth and 18 key informant interviews on purposively selected respondents two each from the 18 senatorial zones of six states in in North East Nigeria.
\end{abstract}

1 IGWE, Dip., B.Sc., M.Sc., M. Phil., PhD. Department of Criminology and Security Studies, Faculty of Social Sciences. National Open University of Nigeria (NOUN). Plot 91, Cadastral Zone, Nnamdi Azikiwe Express Way, Jabi-Abuja Nigeria. Email: princedxn2010@hotmail.com. 


\section{INTRODUCTION}

Every farming system has a boundary which separates it from the larger system that makes up the environment. Conflicts and violent clashes between farmers and nomadic cattle herders have been a common feature of economic livelihood in West Africa (Tonah, 2016). The boundary represents the limits in the larger system; farmers regularly compete with nomadic herders for farmland, pastures, water, trees and the use of rangeland in general (Akpaki, 2012). There have been violent clashes between herders and farmers in several parts of Nigeria for several years, the clashes are occasioned by the destruction of agricultural farms of the farmers by the cattle of the nomadic herdsmen. The upsurge and incessant resource conflicts witnessed as a result of boundary dispute in the tropics have resulted in loss of lives, properties and environmental degradation as also witnessed in some developed countries (Tartes \& Watt et al., 2015).

Naturally, nomadic herders by their nature are migrants who leave their traditional abode in search of greener pasture for their flocks in most cases; their movement is caused by the absence of good and veritable land for their flock to feed on. The environmental degradation is perceived to be contributing enormously to the deterioration in ecosystem services to the environment of various communities. In recent times, Nigeria has witnessed series of violent communal clashes arising from the activities of the herders who move about on a daily basis with their cattle in search of water and greener pastures. They are on the streets in most of the cities and could also be found operating in most remote villages in various states of the country, these herders who are essentially Fulani tribesmen were originally found in small make-shift communities scattered across the northern fringes of Nigeria and other countries in West Africa.

In Nigeria, most herders do not own land but graze their livestock in host communities (Awogbade, 2017), while a few have adopted the more sedentary type of animal husbandry, the increasing crises between farmers and nomadic herders presupposes that, grazing is a major means of animal rearing in Nigeria. The sedentary type of animal husbandry also proves to be more expensive, difficult to manage and inefficient for the rapid growing market of an ever-increasing Nigerian population. Some 
farmers practicing mixed farming revealed that their animals have in one way or another affected other farmers, likewise sedentary pastoralists were in one way or the other affected by farmers (Nformi, Mary-Juliet, Engwali, $\mathrm{Nji}$ 2014). This shows that the issue of farmer-nomadic herders' conflict is more or less shared problem. Therefore, this may not warrant isolation of farmers or pastoralists into ethnic or regional groupings for the sake of levying blames on any as the case may be. Nigeria is experiencing a historic demographic expansion and a spectacular change in food habits, with a population growth nearing $2.8 \%$ per year, according to NPC 2006, the country's own domestic production is far from being able to meet demand, Nigeria is however expected to have a population of over 398 million which is more than the population of Pakistan and Brazil by 2050 (PRB, 2016).

In recent times, the issue of violent clashes and instability between farmers and nomadic herders across the regions in Nigeria has become a major focus to the Nigerian Government, International and National or indigenous development organizations. This to a large extent if not nipped in the bud, may affect the achievement of Sustainable Development Goal 2 which aims at ending hunger, achieving food security and improving nutrition and promoting sustainable agriculture by 2030 . The clashes, has been on the increase exponentially to the dismay of helpless Nigerians (Akpaki, 2012). However, in spite of the spate of violent clashes between nomadic herders and farmers in Nigeria, adequate research attention has not been given to the sociocultural dimension of the conflict with negatively implications on national integration efforts across Nigeria.

Arising from these concerns are the following research questions: what are the socio-economic characteristics of farmers and herders? What are the Factors responsible for farmers/herders' conflicts? what are the Consequences of Farmers/Headers conflicts on national integration? How can these conflicts be solved? Therefore, the study would be guided by the following research objectives to: examine the socio-economic characteristics of farmers and herders; interrogate the factors responsible for farmers/herders' conflict; investigate the consequences of farmers/herder's conflict on national integration; find out how these conflicts can be resolved. 


\section{MAJOR ISSUES IN FARMERS/HERDERS' CONFLICT IN NIGERIA}

Over the years, empirical evidence has revealed various reasons for the continued conflict between herders and farmers in northern Nigeria. Some of the major factors that influence the conflict include; damaging or grazing on Crops; Climatic change; Fresh water scarcity; Negligence and Urbanization.

The notorious intentional grazing on crops has been pointed out as the most predominant cause of conflict between farmers and herders (Adebayo \& Olaniyi, 2008) for herds damaging or grazing on crops and farm land. In a recent study, Adeoye (2017) found deliberate grazing of cattle on crops, farmers' encroachment on grazing reserves, water holes and cattle path sand indiscriminate bush burning by herders as notable causes of conflict between the groups in parts of Kano, Yobe and Borno States of Nigeria. In another study by Adelakun, Adurogbangba and Akinbile (2015) in Kebbi State, about $34.2 \%$ of the farmer sand $6.7 \%$ of the pastoralists indicated that crop damage always triggers conflict between them. The Institute for Peace and Conflict Resolution in conjunction with United Nations Development Programme (IPCR- UNDP, 2012) traced a use of the conflict in Guma and Makurdi LGAs of Benue State to the access and denial of material land resources needed for existence or survival of both man and livestock. Example, the green land and fresh water for the pastoralists that need these for grazing and drinking purposes. Also, land space for occupation which in this instance, the Tiv farmers need to settle for farming activities. Access to these needs are constrained by climatic change resulting in clash of interests and long-standing disagreements.

Climatic change impact on land resources cannot be overemphasised. The encroaching desert to the traditional abode of the pastoralists in the Sahel region has been identified as a factor for the continued clash as herders migrates outward where the grass is much lusher and often intrudes into spaces long claimed or cultivated by settled farmers (Olaniyan et al, 2015). In Jigawa State, the situation has been exacerbated by the phenomenon of climate change which dynamics tend to have been aggravating natural resource conflicts across the region (Okoli \& Atelhe, 2014). 
Climate change and desert encroachment have made southward movements even more inevitable and confrontations with southern farming communities more frequent (Nwosu, 2017).

Similarly, Burton (2016) noted that many of the recent attacks perpetrated by the Fulanis have stemmed from long-standing animosityinduced disagreements with various communities. For instance, Mayah et al (2016) reported that a Fulani leader alleged that them as scare of Agatu people by Fulanis was a reprisal attack against the killing of their prominent on by the people of Agatu in April 2013 who stole his cows. Mostly in the middle-belt, the conflict was found to have stemmed from a long history of feud over farmlands and herding. Preexisting communal conflicts have sustained the violence as herders turned militants in the face of water scarcity, desertification, urbanization, negligence and the indifference of the Nigerian government to their plight (Burton, 2016).

Fresh water scarcity seems to be an under-estimated and under-discussed resource issue facing the world today. It is obvious that the world's water demand grows every year in order to meet up with increasing population. Exacerbated by climate change, fresh water scarcity is creating security concerns in some parts of sub-Saharan Africa, especially in the semi-arid region (Audu, 2013). He argued that avail ability of water which is a major resource needed for agriculture is decreasing as a result of changes in global climatic conditions. Farmers and pastoralists who are the main agricultural practitioners in Nigeria depend on water resources to sustain their vocations. In recent times, access to water and grazing land have become more competitive and has led to violent conflicts on a regular basis between farmers and herdsmen. Jacobs (1980) noted that fresh water scarcity and insufficient rainfall are causes of social and economic ruins which have left the pastoralists at the mercy of sedentary farmers' communities.

Negligence has been identified on the part of both groups as a cause of the conflicts. Yahaya (2008) observed that the herders often left a large number of cattle in the care of children who do not know the consequences in the event of destruction of farm produce. On the other hand, he posits that most farmers usually left their harvested crops on their farm unprotected while others who had poor yield intentionally left them un- 
harvested for cattle to graze so that they could claim heavy compensation. The Nigerian government is as well indicted in this accusation. Burton (2016) noted that government's silence or negligence on the need for increased grazing space has influenced the conflict. He also argued that their quest is not new as the Fulani herders have previously called on the government to rectify the situation. He maintained that there has been little action on the part of the government to resolve these problems and some quarters believe that it is just being politicized for selfish gains. The herders therefore have grown restless and lawless such their impatience has culminated into violent actions and disrespect of traditional authorities in their host communities.

According to Ofem and Inyang (2014), many communities usually collect levies from local crop and livestock (poultry) farmers in their domain and herders normally refuse to pay. This is often perceived as disregard and insult to the traditional authorities. The youth who constitute the local security are usually sent to collect that and the assignment is often met with strict resistance that results to clashes. Similarly, Ofuoku and Isife (2009) equally noted that one of the major causes of the conflict in Bauchi State communities is the disregard for the host traditional authority by the herdsmen.

Increasing Urbanization further complicates the clashes as increased quest to join the league of developed societies has continued to pose a threat to certain agricultural activities in Nigeria. There is increasing erosion of farm and grass lands mostly needed by farmers for planting and herders for grazing. This has deprived the pastoralists of valuable grassland, again forcing them to attempt to expand their "grass kingdom" (Burton, 2016). Other issues identified were indiscriminate bush burning, sexual harassment of women by nomads, harassment of nomads by host youth, theft of cattle and indiscriminate defecation by cattle along the road (Ofem \& Inyang, 2014). It is worthy of note that indiscriminate bush burning can lead to low productivity as result of poor quality of farm lands. However, sexual harassment and rape of women by nomads may lead to contraction of STDs, HIV/AIDS and high rate of unwanted pregnancies among the victims. Also, the defecation by cattle can cause environmental pollution which can pose a health hazard to the inhabitants of the affected areas. 


\section{CONFLICT AND NATIONAL INTEGRATION}

National integration is an elusive coinage for which various scholars have described from different perspectives such as national cohesion, political integration or national integration. While Best, (2006) argued that national integration connotes a community relationship within the same political entity, or a state of mind or disposition to be cohesive, to act together, and to be committed to mutual progress, (Anderson, 1991; Awanyo, 2009) see national integration as an identification of the population with the broader community other than its own group, and the emergence of such bond that does not breach ethnic solidarity. Generally, National integration is a value and a framework that provides environment for mutual cooperation, cross-cultural interactions and articulations that foster interdependency and social harmony needed to drive self-esteem and wellbeing that discourage conflict in society. Whereas conflict has been variously operationalised, the multiplicity of its definition has always pointed at one direction. As an enduring aspect of social existence, it is believed that wherever a community of individual is found, conflict is basically inexcusable. Thus, most conflicts are social in character and usually arise as human beings pursue their different survival and security needs. In this regard, Stagner (2017) defined conflict as a situation in which two or more human beings desired goals which they perceive as being obtainable by one or the other but not yet by both; each party mobilizing energy to obtain a goal, desire objective or situation and each party perceive the other as a barrier or threat to such goal.

The 1999 Nigerian Constitution (as amended) recognizes the importance of national integration in a plural society. Chapter 11 paragraph 15 of the 1999 constitution states that the motto of the Federal Republic of Nigeria shall be "Unity and Faith; Peace and Progress", while paragraph 15 states that, national integration shall be actively encouraged, whilst discrimination on the grounds of place of origin, sex, religion, status, ethnic or linguistic association or ties shall be prohibited. Chapter 11, paragraph 15 of the same constitution also states, inter alia, that "for the purpose of promoting national integration, it shall be the duty of the state to provide adequate facilities for and encourage free mobility of people, goods and 
services throughout the federation, secure full residence rights for every citizen in all parts of the federation and encourage intermarriage among persons from different places of origin or of different religious, ethnic or linguistic ties. In spite of all these provisions, however, Nigerians still live as strangers. Although, the constitution has these robust promises in letter, yet in practice this is far-fetched. When it comes to elections and political appointments, Nigerians are divided along ethnic lines, religion and indigeneship. This is contrary to the essence of national integration or political integration. Arua, (2009) averred that viable political structures such as political parties, trade unions and pressure groups, when they operate effectively, are instruments of integration at the lower level, which in turn serve as basis for a wider and national integration.

\section{CONSEQUENCES OF FARMERS/HERDERS CONFLICTS ON NATIONAL INTEGRATION}

Clashes between farmers and herders have been a major cause of increasing violence and general insecurity in Nigeria. There has been increasing economic adverse effects and social or relational implications such as; distrust between herders and farmers; loss of human and animal lives; family dislocation, displacement of persons and animals; destruction of crops and reprisal attacks.

Historically, Herders and Farmers distrust is a common conflict driver among the group. Burton (2016) noted that majority of the members of the nomadic pastoral group are hardly without connection to their kins across-boundary who are more experienced militants and violent entrepreneurs. This suggests that even those who are peaceful at one time, however, can turn violent at another. Hence, they are largely viewed with suspicion and anger by the sedentary communities on whose land their cattle graze. This has created anti-nomadic sentiments, distrust and altered the mutual relationship that has existed between them and most host communities. The violent disposition of some herders has given rise to anti-nomadic sentiment seen to suggest expansionism and government conspiracy and support in some parts of the north and the south that 
instill hatred (Idowu, 2017; Nwosu, 2017). In Plateau state, the conflict was found to have led to loss of peaceful co-existence, breakdown of established friendship, perpetual fear of attack and loss of family means of livelihood (Umeh \& Chukwu, 2016).

According to Burton, cooperation between innocent citizens, aggrieved Fulani herders and the government is appearing hard to come by, hence, he suggests that the conflict will require multi-level cooperation if it is to be resolved peacefully. The students and teachers of Collage of Education in Kafanchan LGA of Kaduna State were seen scattered in the premises under intense fear as herders left their cattle to invade class rooms during learning session (Channel News Live Report, 2017, June $8^{\text {th }}$ ). That day's academic activities were not only truncated but also the psychological trauma experienced by the students that forcefully ran out of class rooms for fear of harm may not be quantified. The herders were seen roaming the school premises and they left their cattle o move freely inside classroom s until the late intervention of some security personnel.

Above all, following herders/farmers conflict are possibilities of family dislocation, displacement of persons and animals. There were reports of displaced farmers and herders alike. In the host communities, nomadic herders relocate as a result of conflict. Host farmers especially women who stayed behind stop going to distant farms for fear of attack by nomads in the bush (Bello, 1999). Such displaced farmers have become a source of liability to the farmers whom they have to beg for food for themselves and their families. This has created a vicious cycle of poverty in such communities. In Demsa Local Government of Adamawa State, Ofem and Inyang (2014) observed that herdsmen-farmers conflict has not only resulted to internal displacement of herders and farmers, especially women; but also led to reduction in income/savings and crops output because crops are frequently destroy by herders grazing.

This was buttressed by Baud, et al., (1996), who observed that more than 40 million worth of crops are usually lost annually due to invasion of cattle in the North-central region of Nigeria, especially Benue and Plateau States. This has not only created an impediment to the survival of the host communities but has forced many crop-farmers to abandon farming for lesser occupations like Okada (commercial motorcycling) riding 
and other artisan work. Aliyu (2015) argued that the conflict has continued to lead to destruction or loss of properties and crops in these State leaving an already endangered populace even poorer.

The food security welfare of urban well as especially residents of Taraba that depend on these farmers for food supply has been negatively affected since the incessant clashes in Wukari, which is predominantly a farming community and prices of available food supply skyrocketed (Ofem \& Inyang, 2014). Due to the failure of security agencies to control the excesses of the herdsmen, the youth in various communities of Ekiti State have on several occasions launched reprisal attacks on the herder's abodes ("Gaa"), sacking them and destroying their properties (Olugbenga, 2013). There are similar reports in various places in the country. Reports equally indicate similar reprisals indifferent farming communities. A study conducted by Umeh and Chukwu (2016) in Borno State indicated that the economic loss on both conflict ting parties was huge and that the herders seemed to have incurred more in monetary terms than the farmers. While the farmers lost lots of crops and farms to the conflicts, herders lost several cattle and sheep. There verse was the case in Adamawa State, as Adelakun, Adurogbangba and Akinbile (2015) found that farmers were worst hit by the conflicts as it affects their family subsistence farming output and food security.

\section{ORGANISED AND GOVERNMENT INTERVENTIONS}

Organised and Government Interventions in form of early warning and the sampling of some mechanisms of conflict management. In Nigeria, there is some overlap between traditional and religious institutional interventions. Since in some communities' traditional leaders such as emirs are closely linked to their "spiritual" counterparts, government assigns limited roles to these institutions on the bottom rung of the ladder of judicial, political and administrative authority, for example as mediators in disputes. Though conflict management is the jurisdiction of the police, the Nigerian police have been very active in managing conflicts. However, the problem with the police is that the force lacks the capacity to guarantee 
security due to inadequate logistics, particularly mobility, which would enhance their ability to respond to certain types of conflict particularly one between herders and farmer that usually has history of cooperation.

\section{SOME MECHANISMS OF CONFLICT MANAGEMENT}

Two types exit: conventional and orthodox mechanisms. According to Best (2006) some basic strategies of conflict resolution are as follows: Alternative dispute resolution, is about the search for, and application of, "non-conventional" peaceful methods of settling disputes and resolving conflict situations using the least expensive methods, and in ways that satisfy the parties, as well as ways that preserve relationship after a settlement might have been reached. African traditional dispute resolution, according to him, is a method used to resolve conflict by the use of the authority given to the traditional leaders. Africans use collaborative methods of conflict resolution. Another method is Western alternative dispute resolution, which is a process of conflict resolution without violent means. It is also collaborative in nature. Grassroots community-based activities, good governance, collaborations, negotiation, reconciliation, mediation, arbitration, adjudication and crisis management are all elements of western alternative dispute resolution. However, Adebayo and Olaniyi (2008) showed that, informal traditional mechanisms for conflict resolution are still functional in most parts of Nigeria with communal land tenure system (Igwe, 2019). Considering the persistent preference by both crop farmers and pastoralist for the informal conflict arbitration and mediation, points to common desire for sustaining relationships by both parties. This suggests that taking such disputes to formal authority like police/courts of law for prosecution may worsen the relationship between the disputants. Hence, in all, the best way of dealing with conflict situations according to (Alimba, 2014) is to pre-empt or nip them in the bud.

\section{FRUSTRATION-AGGRESSION THEORY}

The place of frustration-aggression Model in Farmer/Herders Conflict and national integration is found within the expectation-reality balance 
that either balances the duo of over stretches it beyond tolerance resulting in aggressive conflict. That is, when people's expectation was not realized, there is tendency for them to confront those they perceived to be responsible for their frustration (Ritzer \& Stepnisky, 2014; Mamdani, 2001). This suggest that the greater the discrepancy between expectation and availability, no matter how marginal it is, the greater the chances of anger and violence reaction. Furthermore, Coleman, (2003) opined that the main explanation of frustration-aggression theory is that aggressive behaviours are not natural but rather result of frustration when certain desires are denied by reason of either direct or indirect societal structural defect. In the context farmers/herders conflict and national integration and in line with Charles (1994) assertion that there must be a clear connection between the social theory and reality to framework empirical discussion.

Therefore, aggressions are ultimately stirred up whenever the cattle eat up cultivated farmlands and destroy the crops in the process, or even trample and compact the soil with their hoofs that render the soil unproductive for planting. Considering the loss incurred by farmers, the farmers retaliate by stealing, poisoning or even killing the herders. Likewise, the herders go as far as harming anyone who tampers with their cattle. The herders are perceived as aggressor, justify with the reality that they go about with some arms and weapons. Situating the frustration-aggression scenario into Nigeria's north-central geopolitical zone, Jibo, Damba, (2017) observed that north-central zone is prone to farmers/herders' conflicts because of frustration arising from failed expectations.

\section{METHODOLOGY}

Using exploratory designs involving qualitative approach, 18 in-depth and 18 key informant interviews were conducted on purposively sampled respondents from the six northeast state's 18 Senatorial district (one IDI and one KII per Senatorial District) for the extraction of primary data that were content analysed. 


\section{AREA OF STUDY/POPULATION}

The study was carried out in senatorial districts of the northeast, Nigeria: Adamawa, Taraba, Bauchi, Gombe, Yobe and Borno, which are areas that favour nomadism due to the presence of the savanna vegetation. The choice of the study area was guided by the report of incessant conflicts between farmers and the herders in most parts of Nigeria, especially in the northeast. The areas are situated within latitudes $9^{\circ}$ and $14^{\circ}$ north of the Equator and longitudes $8^{\circ}$ and $15^{\circ}$ east of the Greenwich Meridian. Yobe, Adamawa, Bauchi, Taraba, Gombe and Borno are in the northeast zone that share boundaries with international communities like the Niger, Chad and Cameroun republics. The study area experiences low rainfall with a short duration and is characterized by acute dryness of the soil, conditions which hardly support luxuriant growth of grass and other flora bio-diversities. However, there is luxuriant growth of trees around riverbeds, mountains and highlands, which supports arable and animal husbandry. The region's population is made up of both sedentary arable farmers and migratory herdsmen, mainly of the Fulani ethnic group. There are about 200 ethnic groups in this zone, among which are the Hausa, Fulani, Tiv, Bachama, Kutep, and Jukun (Olaleye, et al., 2010).

\section{DATA PRESENTATION AND DISCUSSION OF MAJOR FINDINGS}

This section presents the percentage distribution of primary data collected and explanations. Data gathered were transcribed and interpreted in line with study objectives, literature and theories.

\section{OBJECTIVE ONE: The socio-economic characteristics} of farmers and herders

Beyond disruption of family bond, farmer herder conflict endangers the career of students as family bonds are broken. Social networks and capital dislocated (Channel News Live Report, 2017, June $8^{\text {th }}$ ). This position is 
corroborated by the data derived from the field using KII on a respondent who observes:

The family is consistently dislocated and dismembered by conflict between herders and farmers particularly the women and children. ${ }^{2}$

KII respondent has this to say

Change in population size occurred frequently as a result of the aftermath of the conflict between farmers and herders. ${ }^{3}$

Yet, another IDI respondent has this to say

The government should improve security for both herders and farming communities. At a minimum, the federal government and its security agencies should intensify operations against cattle rustlers, improving systems to track livestock movement and trade, arresting individuals who carry illegal firearms and prosecuting suspected assailants. ${ }^{4}$

The data above indicates that conflict affects both the herder and farmers respectively. Above, all it dismembers the family bond. The population size of a nation diminishes as a result of these conflicts.

\section{OBJECTIVE TWO: The factors responsible for farmer herders' conflict}

Farmers usually entrust their herds with the youths who do not take into consideration the consequences of trespassing and destroying farm products (Nzeh, 2015). According to a victim respondent where he says:

The violence resulting from the conflict adversely affects production, marketing and investment in agricultural production. At the time of such

2 KII/Gubio-Adamawa/herder/45years/man/12th Nov., 2019

$3 \mathrm{KII} /$ Bauchi/Bauchi/government official/47years/man/07th Oct., 2019

4 IDI/ Kachalla-Sa/Taraba/herder/35years/man/15th Aug., 2019 


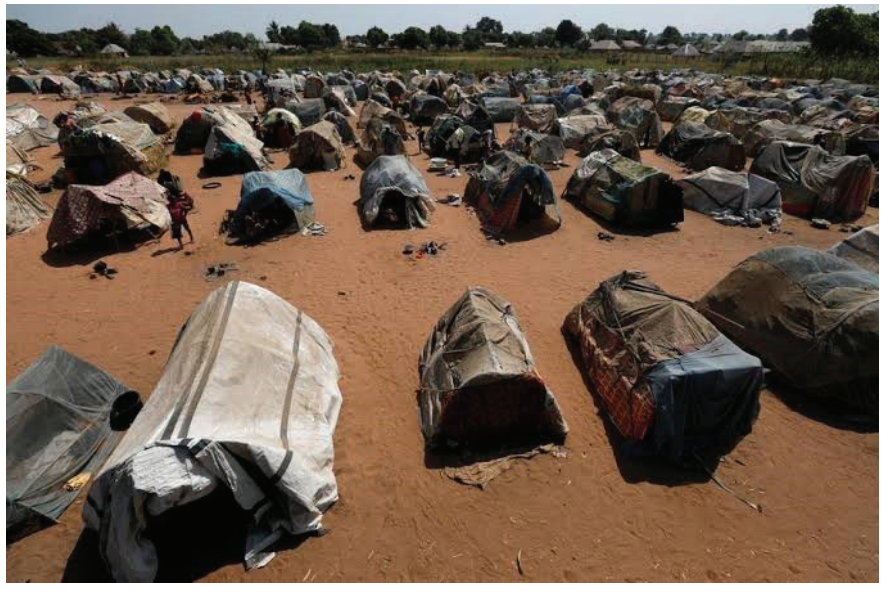

Fig. 1. Human

casualty

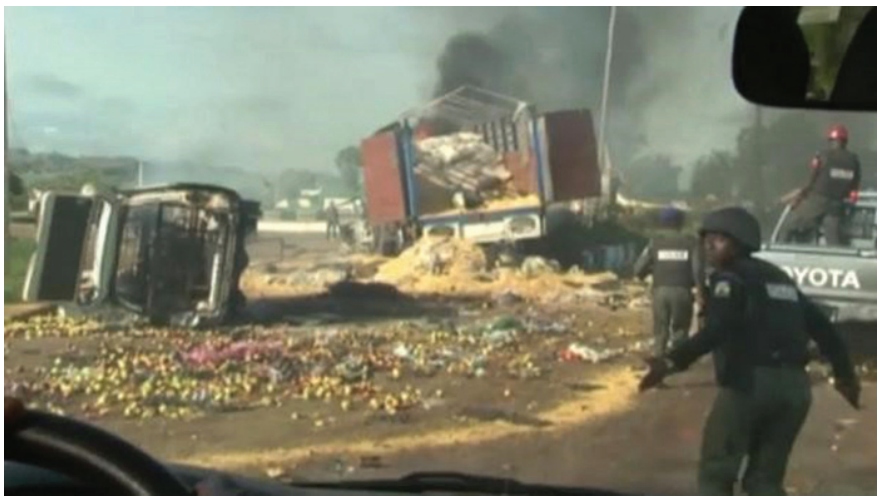

Fig. 2. Destruction of foodstuffs

crisis, farmers who engaged in the cultivation of perishable goods such as vegetables, rice, maize and yam suffer great losses. ${ }^{5}$

Another respondent has this to say:

When the dry season comes and the grasses in the plains start drying, the herders move more towards the greener areas where farms are located and

${ }^{5}$ KII/Takum/Taraba/farmer/48years/man/06th Nov., 2019 
that are when they go on the wildest rampage of eating and destroying farmers' crops. ${ }^{6}$

In another dimension, unregulated grazing pattern is a suspect in intensifying this conflict judging from the position of (Adeoye. 2017). Also, this position is in line with what a respondent says:

The unregulated way of cattle grazing on farmlands by relevant authorities especially the Federal Government of Nigeria. ${ }^{7}$

An IDI respondent has this to say

This was allegedly tied to inequality in conflicting parties accessing government attention. It was alleged that the herders have more money than the farmers, and as a result of that, the herders are not dealt with accordingly when such crisis happened against the farmers. ${ }^{8}$

Another IDI respondent also has this to say

We Kaga stand for justice, fairness and truth. We have never fought any or in any unjust war. We believe what is good for a herder is also good for a farmer. We do not trespass into farming sites to destroy cash crops and so we would tolerate being accused of a crime we did not commit. ${ }^{9}$

Conflict between farmers and herders appears endemic in cases where the government did not provide grazing fields for the herders. The farmers intentionally graze on the farmers crops, polluting the water hole with the cattle dung. Crop damage always triggers conflict between the farmers and the herders in most case. When such happens, the innocent ones bear the consequences at the end.

6 IDI/Damaturu/Yobe/farmer/51years/man/01 Nov., 2019

7 KII/Gubio/Borno/herder/55years/12th Sep., 2019

8 IDI/Nafada/Gombe/farmer/35years/01/Nov., 2019

9 IDI/Kaga/Borno/herder/65years/03/Nov., 2019 
OBJECTIVE THREE: The consequences of farmers/herder's conflict on national integration

Apart from destruction of farm products as a result of farmer herder's conflict, permanent disabilities and loss of human lives were encountered. (Aliyu, 2015). An IDI respondent says:

Although nothing can measure to the loss of lives during the crisis between farmers and herders. It is important to note that some people survive and emerge from the conflict as better people than what they were before the conflict. For instance, I do not store my farm products in the farm anymore waiting for buyers, rather, I take it to the market to sale at the end of cultivation. ${ }^{10}$

Also, another IDI respondent has this to say

The farmer herder's conflict has affected me because when we migrate to the Southern parts of Nigeria they do not allow our cattle to graze and they also steal our cattle. So due to this we protect ourselves and the cattle. ${ }^{11}$

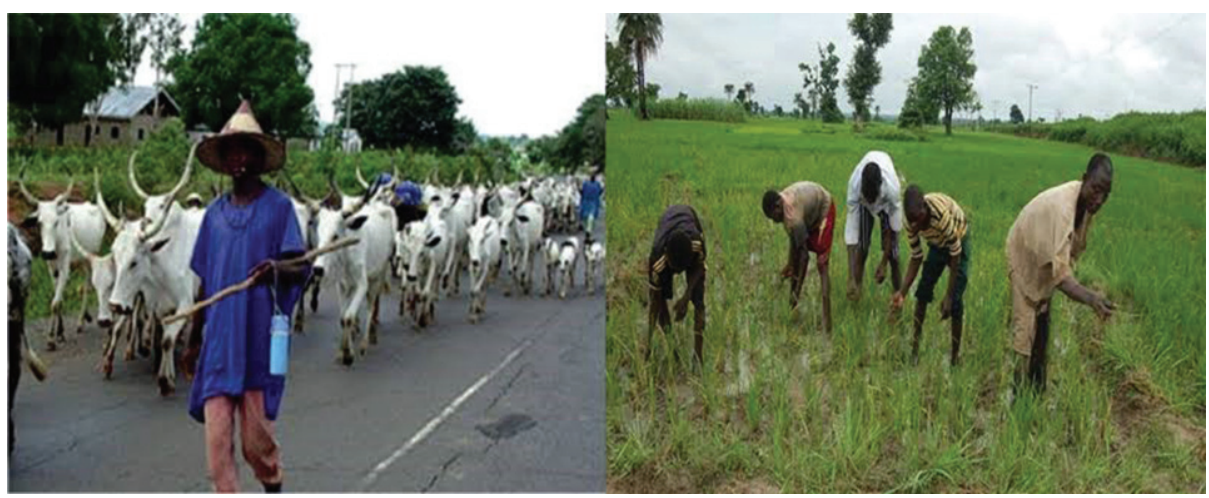

Fig. 3. Rrepresents a new beginning

${ }^{10}$ IDI/Jukun/Taraba/farmer/35yeras/15 Aug., 2019

11 IDI/Katagun/Bauchi/herder/37years/01 Nov., 2019 
The respondents above indicated that, rather sulking, mourning for the loss of the loved ones and migrating, one can make better choices by deciding to take advantage of surviving the hurdle and coming up with better strategies as to how to protect your farm products and your cattle.

Yet, another IDI says

The elders do not appear to have the last word on vital issues affecting land conflict as it was in the past. The discouraging docility of our elders is costing us our lives and identity source such as our land. ${ }^{12}$

Some Village heads, elders and community leaders are not fully participating in the way and manner a leader ought to behave, in the sense that most of them have sold their dignity for worldly things and in return the individuals in their community tend to lose trust in them and sees them as people who only care about their interest and not that of the masses.

\section{OBJECTIVE 4: How these conflicts can be resolved}

Traditional and religious groups are not being considered key parties in curtailing the menace of farmer herder's conflict (Egbodi, 2010). An IDI respondent says:

Traditional and local leaders should be well involved in finding solutions to farmer/herdsmen conflict. ${ }^{13}$

Yet, another KII respondent says

Social attitude to sharing and cultural exchanges should be encouraged between different ethnic groups even if they stay at peace. ${ }^{14}$

12 IDI/Gombe/Gombe/government official/65years/man/07 Aug., 2019

13 IDI/Ningi/Bauchi/Village head/60years/man/01 August., 2019

${ }^{14} \mathrm{KII} /$ Potiskum/Yobe/Government Official/45years/man/07 Sept., 2019 
KII respondents has this to say

Education between the two parties (Farmers and Herders) should be realistically encouraged. ${ }^{15}$

Another respondent says:

A law should be placed by the government in power to stop them from grazing in our farm land; they should be arrested and prosecuted; they should be killed to put a total stop to all these problems. ${ }^{16}$

Local and community-based dispute resolution mechanisms have proved effective in both averting violence and helping communities recover from conflict. Forums that allow various constituencies - farmers, pastoralists, community vigilantes and state security agencies - to monitor, identify, discuss and manage potential threats can be particularly helpful in resolving conflict. Sensitization of both farmers and herders can be considered as a strong tool in curtailing farmer herder's conflict in Nigeria. In the process of sensitizing the farmer and herders, each group get to

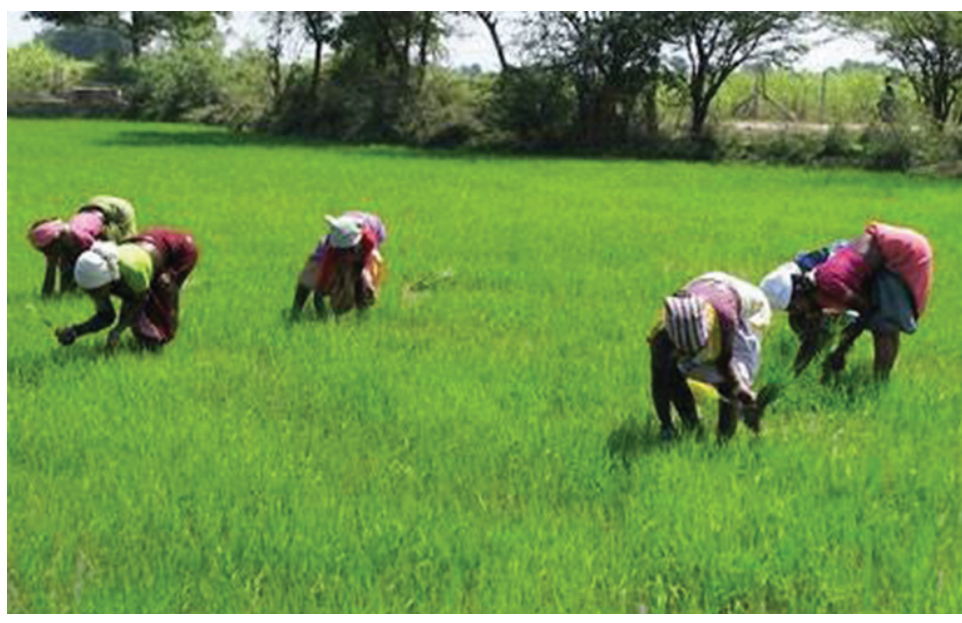

Fig. 4.

Vulnerable farm crop from soft loans being put into use

$15 \mathrm{KII} /$ Dong/Borno/Government official/man/03 Nov., 2018

16 KII/Damaturu/Yobe/farmer/35years/man/12th Nov., 2019 
know and understand what ought to be done and how well to go about it at the right time. For example, farmers and herders get to know the implication of trespassing. Soft loans can also be issued to beneficiaries of the sensitization in order to encourage them and also to motivate others to be part of the sensitization program.

Responses received as reflected in fig 3 confirmed that the farming system in Nigeria, like most parts of the world is characterized by ancient pre-colonial boundaries different from colonial and post-colonial boundaries, which separates it from the larger system that makes up the environ-

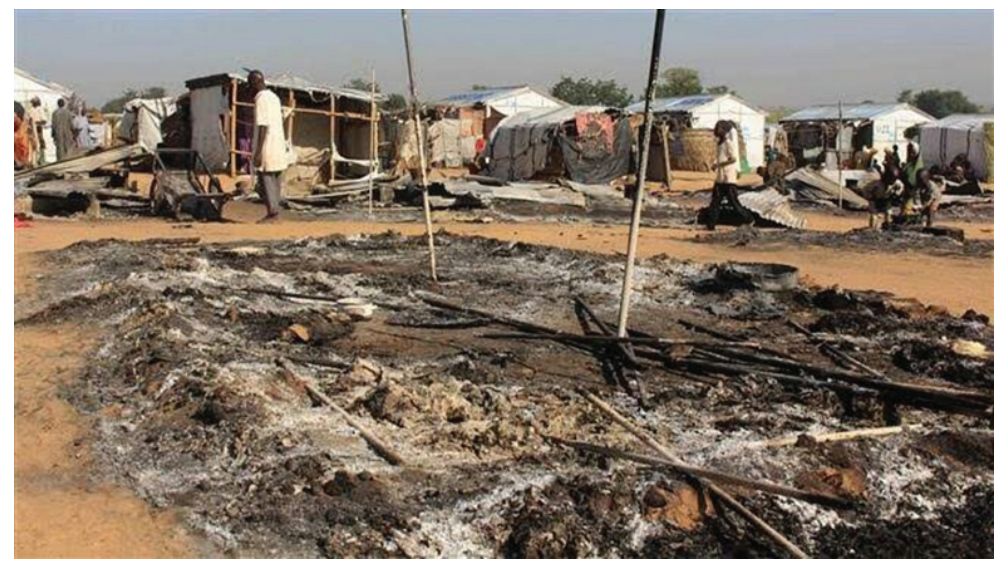

Fig. 5. Destructive arson effect of herders/farmers conflict

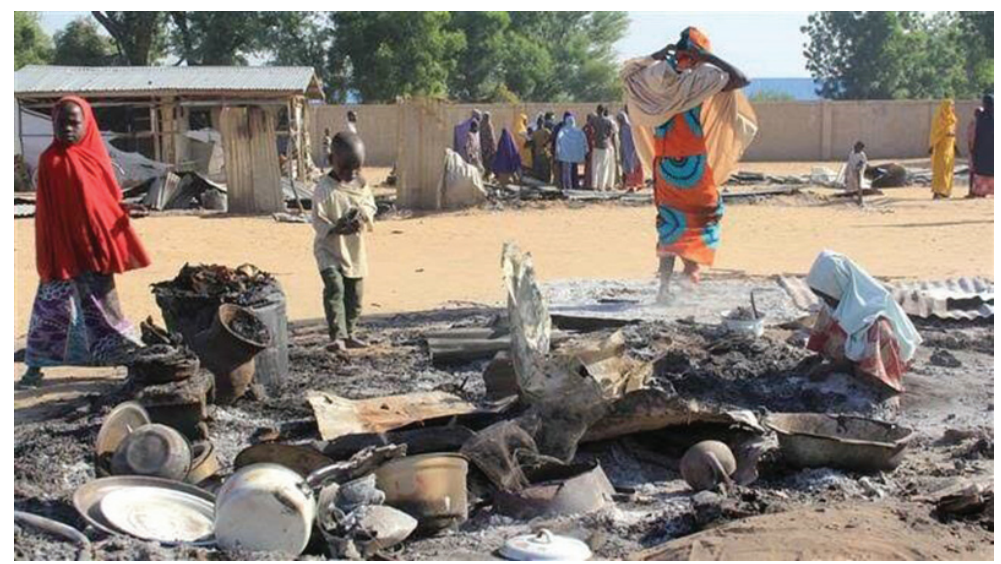

Fig. 6. Destructive arson effect of herders/farmers conflict 


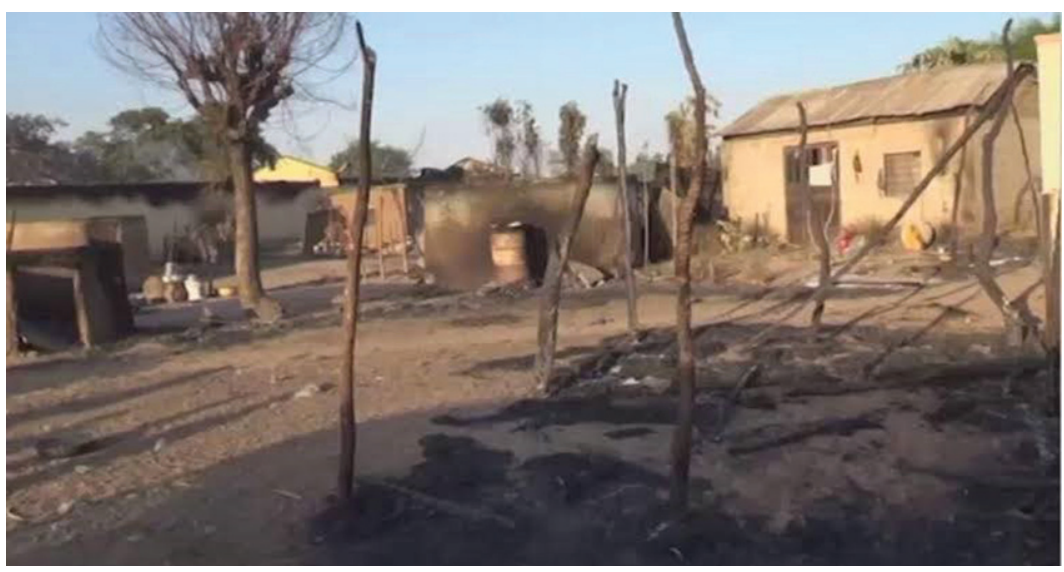

Fig. 7. Destructive vandalism effect of herders/farmers conflict

ment. Respondents were also of the view that conflicts and violent clashes between farmers and nomadic cattle herders have been a persisting feature of most communities in Nigeria. There was also agreed views of the respondents that farms and boundaries therefrom are meant to define limits movement and encroachment as farmers regularly compete with nomadic herders for farmland, pastures, water, trees and the use of rangeland in general. However, it is a known fact that naturally, nomadic herders by their nature are migrants who leave their traditional abode in search of greener pasture for their flocks. Mostly, their movement is caused by the absence of good and veritable land for their flock to feed on. Yet, responses received as contained in fig 4 confirmed that due to encroachments and/or eradication of grazing routes occasioned by farming activities, movements of herdsmen, either by omission or commission, fail to observe and respect restrictions designed by farmland boundaries. Respondents believe that the failure to observe and respect these limitations and restrictions have generated reoccurring clashes and violence between herders and farmers in several parts of Nigeria.

Respondents also confirmed that farmers-herders clashes and its resultant violence result most times from incidences of destruction of agricultural farms of the farmers by the cattle of the nomadic herdsmen. Respondents were however, agreed that the clashes and violence has 
inflicted varied damages to the psyche, socio-economic well-being and socio-political and economic stability of various communities and the nation at large. According to the views expressed by the respondents, farmers/herders' conflict does not only constitute security threat to National Integration but equally impedes socio- economic development of Nigeria and requires effectively coordinated efforts to arrest the situation.

\section{SUMMARY}

Farming system in Nigeria, like most parts of the world is characterized by boundaries and crisis of sociocultural limits. Conflicts and violent clashes between farmers and nomadic cattle herders have been a persisting feature of most communities in Nigeria resulting from culturally derived identity issues that divide them into in-group and out-group. These boundaries are meant to define limits movement and encroachment as farmers regularly compete with nomadic herders for farmland, pastures, water, trees and the use of rangeland in general, hence, persistent conflict of interest. However, it is a known fact that naturally, nomadic herders by their nature are migrants who leave their traditional abode in search of greener pasture for their flocks. Due to encroachments and/or eradication of grazing routes occasioned by farming activities, their movements, by omission or commission, fail to observe and respect cultural restrictions designed by farmland owners. The failure to observe and respect these restrictions has generated reoccurring clashes and violence between herders and farmers in several parts of Nigeria. These clashes and violence result most times from incidences of destruction of agricultural farms of the farmers by the cattle of the nomadic herdsmen. These have inflicted varied damages to the psyche, sociocultural, socioeconomic and by extension sociopolitical well-being of the people and communities across Nigeria. Farmers/herders' conflict however, endangers security of life, property and quest for national integration. 


\section{CONCLUSIONS}

Conflicts and violent clashes between farmers and nomadic cattle herders have been a persisting feature of most communities in Nigeria resulting from culturally derived identity issues that divide them into in-group and out-group. These boundaries are meant to define limits movement and encroachment as farmers regularly compete with nomadic herders for farmland, pastures, water, trees and the use of rangeland in general, hence, persistent conflict of interest. The study has adequately evaluated the cultural context of farmers-herders conflicts and thus, concludes that conflicts and violent clashes between farmers and nomadic cattle herders have been a persisting feature of most communities in Nigeria thereby creating boundaries that are meant to define limits to movement and encroachment as farmers regularly compete with nomadic herders for farmland, pastures, water, trees and the use of rangeland in general. The failure to observe and respect these limitations and restrictions has generated reoccurring clashes and violence between herders and farmers in several parts of Nigeria. These clashes and violence result most times from incidences of destruction of agricultural farms of the farmers by the cattle of the nomadic herdsmen which have inflicted varied damages to the psyche, socio-economic well-being and socio-political and economic stability of various communities and the nation at large. Farmers-herders' conflict endangers national integration and coexistence.

\section{RECOMMENDATIONS}

Since Farmers-Herders conflict drivers revolve around settlement boundary, sociocultural identity, and socioeconomic survival, there is need therefore for policy that provides legal framework that clearly defines boundaries of indigeneship and limit of settlers. These boundaries are meant to define limits movement and encroachment as farmers regularly compete with nomadic herders for farmland, pastures, water, trees and the use of rangeland in general, hence, persistent conflict of interest. From the results of the findings, the following recommendations were made; Repre- 
sentatives of the host communities and Fulani herdsmen should be compelled to regularly meet to engage and address common concerns. Participatory planning process that involves all stakeholders (farmers-herders) in the dispute resolution mechanism should be adopted. Ranching method of cattle rearing should be adopted at rearing location across the country while the herdsmen should be given needed training for effective and efficient management of the ranching. Government need facilitate proper re-orientation about national integration and patriotism across ethnic and religious divide while being firm and fair in its involvement in its resolution and implementation of decisions.

\section{BIBLIOGRAPHY:}

Abdulbarkindo, A., Alupse, B. (2015). Migration and violent conflict in divided societies: Non-BokoHaram violence against Christians in the Middle Belt region of Nigeria. Nigeria Conflict Security Analysis Network (NCSAN), Working Paper No.1, Abuja, p. 1-49.

Adebayo, O.O., Olaniyi, O.A. (2008). Factors associated with pastoral and crop farmers conflict in derived Savannah Zone of Oyo State, Nigeria. Journal of Human Ecology, Vol. 23, No. 1, p. 71-74.

Adelakun, O.E., Adurogbangba, B., Akinbile, L.A. (2015). Socioeconomic effects of farmer-pastoralist conflict on agricultural extension service delivery in Oyo State, Nigeria. Journal of Agricultural Extension, Vol. 19, No. 2, p. 59-70.

Adeoye, N.O. (2017). Land use conflict between farmers and herders in parts of Kano, Yobe and Borno States of Nigeria: Nomads' viewpoints. Ghana Journal of Geography, Vol. 9, No. 1, p. 127-151.

Akpaki, A.Z. (2012). Ackerbavern and mobile fierhatter in zentral and nord Benin.

Dietrich Reiner Verlag.

Alimba, N.C. (2014). "Probing the Dynamic of Communal Conflict in Northern Nigeria," Africa Research Review: An International Multidisciplinary Journal, Ethiopia, Vol. 8, No. 1, Serial No. 32, January, p. 177-204.

Aliyu, A.S. (2015). Causes and resolution of conflict between cattle herders and crop farmers in Katsina State. A Published M.Sc. Dissertation by the School of Postgraduate Studies, Ahmadu Bello University, Zaria, p. 1-74.

Anderson B., (1991). Imagined Communities: Reflections on the Origin and Spread of Nationalism (Verso, London). 
Arua, E.O. (1999). Relationship of man to land in Nigeria.Beitr. Trop. Landwirstsch. Veterinaries Press.

Audu, S.D. (2013). Conflicts among Farmers and Pastoralists Iin Northern Nigeria Induced By Fresh water Scarcity. Developing Country Studies, Vol. 3, No. 12, p. $25-32$. Awanyo, L. (2009). 'Exploring the connections: land tenure, social identities, and AgroBiodiversity practices in Ghana', Geo- grafiskaAnnaler: Series B, Human Geography Vol. 91, No. 2, p. 137-155.

Awogbade, M.O. (2017). Grazing reserves in Nigeria. Nomadic Peoples, Vol. 23, p. 18-30. Baud, M., Koonings, K., Oostindie, G., Ouweneel, A., Silva, P. (Eds.). (1996). Etnicidadcomoestrategia en America Latina y el Caribe (Abya-Yala, Quito).

Bello, S.O. (1994). The Politics of Land Reform in Nigeria: A study of the Land Use Act and the Peasantry of Oyo State, A Ph.D thesis, Department of Political Science, Faculty of the Social Sciences, University of Ibadan, Nigeria.

Best, S.G. (2006). "The Political Dimensions of Conflicts in the Benue Valley," in Gyuse, T.T., Ajene, O. (eds), Conflicts in the Benue Valley.

Burton, G. (2016). Background report: The Fulani herdsmen. Project Cyma Publication. November, p. 1-18.

Channels News. (2017). News across Nigeria: Teachers, residents lament cattle invasion in Edo school. Live Video, Retrieved 11 $1^{\text {th }}$ June, 2017 and Available at: https://www. youtube.com/watch?v=NWccQWF4mhU.

Charles, J.O. (2005). Sociological Theory: A historic-analytical approach on man and society. Lagos: Serenity.

Coleman, P.T. (2003). Characteristics of protracted, intractable conflict: Towards the Development of a meta-framework-I. Peace and Conflict: Journal of Peace Psychology, Vol. 9, No. 1, p. 1-37.

Coser, L.A. (2016). The Function of Social Conflicts. New York; the free press.

Damba, O. (2017). Climate Change and Inter-Ethnic Conflict between Fulani herders and Host Communities in Nigeria. Being a Paper Presented at Conference on Climate Change and Security Organized by the Norwegian Academic of Sciences and Letters on the Occasion of 250 years Anniversary in Trondiem, Norway 2017.

Dougherty, J.E, Pfaltygraff. (2011). Contending theories of international relations. New York: Harper and row.

Egbodi, E. (2010). The Fulani herdsman in Nigeria: questions, challenges, allegations. http://elnathanjohn.blogspot.com/2014/03/the-fulani-herdsman-in-nigeria.html. Accessed 23 November 2014.

Hagberg, S. (2018). Between Peace and Justice Dispute Settlement between Karaboro Agriculturalist and Fulbe agro-Pastoralist in Burkina Faso. Uppsala studies in cultural Anthropology, 25.

Idowu, A.O. (2017). Urban violence dimension in Nigeria: Farmers and herders onslaught. AGATHOS International Review, Vol.8, No. 14, p. 187-206. 
Igwe, D.O. (2019). The Sociohistorical Context of Ezillo and Ezza Land Conflict in Ezillo Community, Ebonyi State, Nigeria, Ph.D. Thesis Department of Sociology, Faculty of the Social Sciences, University of Ibadan, Nigeria.

Jacobs, A. (1980). Pastoral Maasai and tropical rural development. In R. Bates, M. Lofchie (ed.). Agricultural development in Africa: Issues of public policy. New York: Praeger Publishers.

Mamdani, M. (2001). Beyond Settler and Native as Political Identities: Overcoming the Political Legacy Colonialism. In Ozo-Eson, Peter \& Ukiwo Ukoha (eds) Ideology and African Development.CASS \& AFRIGOV.

Mayah, E., Tukur, S., Adebayo, H. (2016). Exclusive: Why we struck in Agatu - Fulani herdsmen. PremiumTimes. Retrieved 14 ${ }^{\text {th }}$ June, 2017, from http://www.premiumtimesng.com/news/headlines/200426- exclusive-struck-agatu-fulani-herdsmen.html.

Nwosu, C. (2017). Between Fulani herders and farmers. Retrieved $15^{\text {th }} J u n e, 2017$ from http://www.republic.com. ng/aprilmay-2017/fulani-herdsmen-farmers/.

Nzeh, E. (2015). The Effects of Migration by Nomadic Farmers in the Livelihoods of Rural Crop Farmers in Enugu State, Nigeria. Global Journal of Science Frontier Research: Agriculture and Veterinary, Vol. 15, No. 3.

Ofem, O.O., Inyang, B. (2014). Livelihood and conflict dimension among crop farmers and Fulani herders in Yakurr Region of Cross River State. Mediterranean Journal of Social Sciences, Vol. 5, No. 8, p. 512-519.

Okoli, A.C., Atelhe, G.A. (2014). Nomad saga initiatives: A political ecology of herder/ farmer conflicts in Nasarawa State, Nigeria. American International Journal of Contemporary Research, Vol. 4, No. 2, p. 76-88.

Olaniyan, A., Francis, M., Okeke-Uzodike, U. (2015). The cattle are "Ghanaians" but the herders are strangers: Farmer-herder conflicts, expulsion policy and pastoralist question in Agogo, Ghana. African Studies Quarterly, Vol. 15, No. 2, p. 53-67.

Olaleye, R.S., Odutola, J.O., Ojo, M.A., Umar, I.S, Ndanitsa, M.A. (2010). Perceive defectiveness of conflict resolution methods for improved farmer-pastoralist relationship in Chikun Local Government Area of Kaduna State, Nigeria. Nigerian Journal of Rural Extension \& Development, Vol. 3, p. 54-58.

Olugbenga, E.O. (2013). The impact of migration on internal security: The case of itinerant Fulani herders in Ekiti State, South West Nigeria. IOSR Journal of Humanities \& Social Science (IOSR-JHSS), Vol. 16, No. 3, p. 77-82.

Ritzer, G., Stepnisky, J. (2014). Sociological theory. (9th $e d$.$) . Singapore: McGraw-Hill.$ Stagner, R. (2017). Psychological aspects International Conflicts: Brooks \& Cole Tonah, S. (2006). Managing farmer-herder conflicts in Ghana's Volta Basin. Ibadan Journal of Social Sciences, Vol. 4, No. 1, p. 33-45.

Umeh, G.N., Chukwu, V.A. (2016). Socioeconomic perspectives to arable crop farmerherder conflicts in Ebonyi North Zone, Ebonyi State, Nigeria. International Journal of Science \& Research (IJSR), Vol. 5, No. 5, p. 135-142. 